\title{
Biochemical Dymorphism of Potassium Content and its Adaptive Significance in Domestic Reindeer
}

\author{
Alexander Yuzhakov ${ }^{1}$, Anatoly Kushnir ${ }^{2}$, Kasim Laishev ${ }^{*}$, and Vasily Zabrodin ${ }^{1}$ \\ ${ }^{1}$ SPC RAS, 7, sh. Podbel'skogo, St. Petersburg-Pushkin, 196608 Russia \\ 2 IC\&G SB RAS, 10, Lavrenttjeva, Novosibirsk, 630090 Russia
}

\begin{abstract}
The connection between the types of potassium concentration and the ecogenesis of the studied groups of animals, with the degree of extreme conditions of breeding, with types of potassium in extreme conditions of breeding is known. In this regard, studies on autochthonous species of ungulates in the Subarctic are of great interest, the most numerous of which is the reindeer (Rangifer tarandus). Comparative analysis of the adaptive responses of NK and LK types at different levels of organization confirmed the presence of the adaptive advantage of animals characterized by a hereditarily high concentration of potassium in the blood in ecological-geographical zones with extreme environmental conditions. As a result of a study on domesticated reindeer, a clearly expressed dimorphism in the level of potassium in the blood was revealed, due to a genetically controlled high NK and low LK concentration. The average level of potassium in whole blood in the studied population of reindeer is $26.94 \pm 0.56 \mathrm{meq} / \mathrm{l}$ with a variability of $24.61 \%$. It was revealed that the average level of potassium content in whole blood by sex and age was distributed as follows: whales $22.97-25.80 \mathrm{meq} / \mathrm{l}$ at $\mathrm{P}>0.05$, castrate bulls had indicators significantly higher than 28.37 - 29.58 meq / l, at P> 0.05 , the young showed intermediate indicators $-27.37-28.13$ at $\mathrm{P}>0.05$. The intragroup variability in potassium content in whole blood ranged from 15.5 to $31.05 \%$. It was found that in domestic reindeer the ratio of animals of the high-potassium (HK) type is $88.02 \%$ and of the lowpotassium (LK) type - $11.98 \%$, while the gene frequencies for highpotassium animals are 0.9381 .
\end{abstract}

\section{Introduction}

The study of genetically determined biochemical polymorphism in different animal species in order to differentiate and use monogenic biochemical traits as genetic markers is the subject of the works. For this purpose, blood proteins, electrolyte and trace element ions were studied in various domestic and farm animals. Special attention was paid to various proteins and ionic concentrations, which determine the degree of adaptation to extreme environmental factors. In this area of research, attention is drawn to the study of polymorphism in the concentration of potassium in the blood of animals with the determination of the adaptive significance of different genetically controlled types.

\footnotetext{
* Corresponding author: layshev@mail.ru
} 
Potassium is widely distributed in nature in the form of various salts. Along with other electrolyte ions, for example, with $\mathrm{Na}+$, it is an indispensable bioelement for animals. Potassium is a biostimulator of many metabolic processes in the body. For example, protein synthesis by ribosomes and glycolysis requires a high concentration of potassium, since it is necessary to ensure the maximum activity of pyruvate kinase [1]. The accumulation and release of energy in the body occur with the participation of potassium. Stimulating the formation of acetylcholine, potassium is involved in the conduction of a nerve impulse in synapses, stabilizes the heart rate [2]. In the process of respiration, potassium acts as a stimulating agent, due to the stabilization of large protein molecules, in particular hemoglobin. Thus, maintaining the constancy of the concentration of potassium and its satellite sodium in erythrocytes and plasma is an important biochemical and physiological condition for the normal functioning of blood systems, and therefore the whole organism.

It is known that the existing interspecific and intraspecific differences in the level of potassium concentration in the blood make it possible to single out two main systems in mammals [3]. This is a low concentration of potassium (dog, cat, arctic fox, mink, fox), high-in humans, monkeys, horses, marals, spotted deer, rats. Representatives of the Bovidae family have been found to have polymorphism based on genetically determined levels of potassium in the blood, i.e. animals with both low (LK) and high (NK) concentrations of this bioelement are present. The relationship between the types of potassium concentration with the ecogenesis of the studied groups of animals, with the degree of extreme conditions of breeding, with types of potassium in extreme conditions of breeding was revealed. In this regard, studies on autochthonous species of ungulates in the Subarctic are of great interest, the most numerous of which is the reindeer (Rangifer tarandus).

One of the first attempts to isolate ecogenetic types based on polymorphic blood systems in reindeer was the research of [4].

Aboriginal breeds of animals bred in a continental climate and strict natural selection, as a rule, have a high concentration of potassium in the blood, and in factory breeds - low concentrations of potassium $[3,5,6]$.

Comparative analysis of the adaptive responses of NK and LK types at different levels of organization confirmed the presence of the adaptive advantage of animals that are distinguished by a hereditarily high concentration of potassium in the blood in ecological-geographical zones with extreme environmental conditions. Studies to determine the relationship between the concentration of potassium in the blood and economically useful traits have shown that productivity in some cases is higher in animals of the NK-type, and in others in representatives of the LK-type [3, 7]. The use of potassium salts in the feeding of various types of farm animals and poultry contributed to an increase in their reproductive qualities, stimulated the growth of young animals. [8, 9, 10, 11].

A comprehensive study of genetically determined adaptive qualities of domesticated reindeer is still the most urgent task of ecological genetics and physiology today.

When carrying out the work, we set the following tasks:

- study of the level of potassium in the blood and the presence of dimorphism on this basis in domestic reindeer;

- study of the level of potassium in the blood and the presence of dimorphism on this basis in different sex and age groups of deer (young animals, whales, castrate bulls).

\section{Materials and methods}

Field research was carried out on domesticated reindeer grazing on the farms of the Yamal and Priuralsky districts of the Yamalo-Nenets Autonomous Okrug. The blood was taken from vampires (2-10 years old), castrated bulls (2-10 years old) and young animals (from 6 to 18 months old). Deer blood sampling was carried out in November, during the mass slaughter. Blood was taken from the cervical vein (V. Saphena) using a needle and collected in glass tubes, which were frozen for further transportation. Before analysis, blood was stored in a freezer at $-18^{\circ}$.

Determination of potassium concentration. A raw blood sample was taken from a mixed raw sample, the volume of raw blood was $5 \mathrm{ml}$. Wet ashing of samples - liquid samples up to $5 \mathrm{ml}$ in volume were treated with boiling strong oxidants and their vapors.

The determination of the potassium content was carried out on an atomic absorption spectrophotometer "KVANT-2A". 
Blood samples were passed in batches of 20, each batch was repeated and the data were taken into account only when both sample determinations coincided within the instrument error $( \pm 5 \%)$.

The concentration of potassium in the blood was expressed in meq/l of whole blood.

The obtained data on the concentration of potassium ions were processed statistically [12].

The HK and LK gene frequencies in the study groups were calculated using the formula: recessive gene frequency

$$
\mathrm{H} / \mathrm{K}=\sqrt{ }(\mathrm{HK} \%) / 10
$$

the formula for calculations is applied by researchers conditionally in order to be able to compare their own data with the data of other authors published in the scientific literature.

\section{Research results}

Two groups of animals $(n=142)$ were taken from a herd of domesticated reindeer, in which the potassium electrolyte was determined.

Table 1 shows that in each studied group of deer there are animals with both high (25 - 41.4 meqv/l) and low levels of potassium in the blood (up to $20 \mathrm{meq} / \mathrm{l}$ ).

Table 1. Potassium content in the blood of domesticated reindeer.

\begin{tabular}{|c|c|c|c|c|}
\hline \multirow{2}{*}{$\begin{array}{c}\text { Group of } \\
\text { animals }\end{array}$} & $\mathrm{n}$ & \multicolumn{3}{|c|}{ Average level of potassium in the blood, meqv/l } \\
\cline { 3 - 5 } & & $\lim$ & $\mathrm{M} \pm \mathrm{m}$ & $\mathrm{Cv}, \%$ \\
\hline 1 group & 49 & $11,5-41,1$ & $25,21 \pm 0,98$ & 27,15 \\
\hline 2 group & 93 & $11,7-41,4$ & $27,89 \pm 0,67$ & 22,78 \\
\hline Joint group & 142 & $11,5-41,4$ & $26,94 \pm 0,56$ & 24,61 \\
\hline
\end{tabular}

The data in the two fixed and combined groups have an indicator of the same level (25.21 - 26.94 meqv/l) and do not have significant differences $(\mathrm{P}>0.05)$. The value of variability for this indicator, both in the first two groups of animals and in the combined group, have values of the same order of magnitude (22.8 - 27.1\%). Hence, we can state the fact that the average value of the potassium content in the blood of domesticated reindeer is characterized by a high indicator.

In each of the studied groups of animals and in the combined group, the components were: whales, bulls and young animals. From the data given in Table 2, it can be concluded that the blood system of domestic reindeer is dimorphic in terms of potassium concentration and can be represented by many ecotypes.

We differentiated animals into high-potassium (HK) type and low-potassium (LK) type by analogy with the literature data: animals with a potassium level not exceeding $18-20 \mathrm{meq} / \mathrm{l}$ in whole blood were attributed to a low-potassium type (LK), and animals with a level from $22 \mathrm{meq} / \mathrm{l}$ in whole blood and above were assigned to the group of high potassium type (NK).It was found (Table 2) that in each age and sex group, the average indicator of the level of potassium in the blood gives grounds to classify the animals of the group as the high-potassium type.

Table 2. Average level of potassium in the blood of deer by sex and age differentiation.

\begin{tabular}{|c|l|c|c|c|c|}
\hline \multirow{2}{*}{$\begin{array}{c}\text { Group of } \\
\text { animals }\end{array}$} & \multicolumn{1}{c|}{$\begin{array}{c}\text { Sex of } \\
\text { animals }\end{array}$} & \multirow{2}{*}{$\mathrm{n}$} & \multicolumn{3}{|c|}{ Average level of potassium in the blood, meqv/l } \\
\cline { 4 - 7 } & & & $\lim$ & $\mathrm{M} \pm \mathrm{m}$ & $\mathrm{Cv}, \%$ \\
\hline \multirow{3}{*}{1} & females & 28 & $11,51-38,37$ & $22,97 \pm 1,25$ & 28,84 \\
\cline { 2 - 6 } & males & 6 & $24,25-35$ & $28,37 \pm 1,80$ & 15,55 \\
\cline { 2 - 6 } & calves & 15 & $19,95-41,06$ & $28,13 \pm 1,74$ & 24,01 \\
\hline \multirow{3}{*}{ Joint group } & females & 23 & $15,0-38,7$ & $25,80 \pm 1,40$ & 24,95 \\
\cline { 2 - 6 } & males & 37 & $12,9-41,4$ & $29,58 \pm 1,51$ & 31,05 \\
\cline { 2 - 6 } & calves & 33 & $11,7-38,7$ & $27,37 \pm 1,15$ & 23,70 \\
\cline { 2 - 6 } & females & 50 & $11,51-38,70$ & $24,19 \pm 0,93$ & 27,13 \\
\cline { 2 - 6 } & males & 43 & $12,9-41,4$ & $29,41 \pm 0,87$ & 19,58 \\
\cline { 2 - 6 } & calves & 49 & $11,7-41,06$ & $27,61 \pm 1,12$ & 27,81 \\
\hline
\end{tabular}


But the variability of this indicator indicates that within the groups there are animals and low potassium. Males in each of the comparable groups have significantly higher mean blood potassium levels compared to females ( $\mathrm{P}<0.001)$, females and calves ( $\mathrm{P} 1<0.001, \mathrm{P} 2<0.001)$, as well as in the combined group with females $(\mathrm{P}<0.001)$ and calves $(\mathrm{P}<0.001)$, in males the variability of the indicator is lower than in animals of other groups.

In young animals, both in the first and in the second group, the average potassium in the blood of the same level $(\mathrm{P}>0.05)$ and the variability of the indicator does not have significant differences (23.7-24.01\%). In the combined group of deer, the average level of potassium in whole blood is of the same order of magnitude $(\mathrm{P}>0.05)$.

In young animals, both in the first and in the second group, the average potassium in the blood of the same level $(\mathrm{P}>0.05)$ and the variability of the indicator does not have significant differences (23.7-24.01\%). In the combined group of deer, the average level of potassium in whole blood is of the same order of magnitude ( $\mathrm{P}>0.05)$.

Average level of potassium in blood in deer of high potassium (HK) and low potassium (LK) types

The revealed dimorphism in the content of potassium in the blood of domesticated reindeer reveals the breadth of research - the difference in the percentage ratio of animals of NK and LK types.

From the data in Table 3, it can be seen that in all groups of animals, the average level of potassium in the blood of animals of the compared types (NK) has high rates and with indicators of the low-potassium type (LK) have significant differences $(\mathrm{P}<0.001)$. The variability of the indicator in animals of the same order of magnitude (14.9 - 17.3\%). The percentage of high-potassium animals in the groups is very high (85.7 - 89.2\%). The data on the content of the average level of potassium in the blood in animals of the low-potassium type differ significantly from the indicators of highpotassium animals $(\mathrm{P}<0.001)$, and there are no significant differences between the groups of animals in terms of the potassium content related to high-potassium $(\mathrm{P}>0.05)$ and the coefficient of variability of the indicator in the (LK) type of animals in all studied groups is lower than in the group of animals of the high-potassium type (3.1 - 13.14\%)

Table 3. Potassium content in the blood of HK and LK types of domesticated reindeer, meq/l .

\begin{tabular}{|c|c|c|c|c|c|c|}
\hline $\begin{array}{c}\text { Group of } \\
\text { animals }\end{array}$ & A type & $\mathrm{n}$ & $\%$ & $\mathrm{M} \pm \mathrm{m}$ & $\mathrm{Cv}$ & $\begin{array}{c}\text { Gene } \\
\text { frequencies }\end{array}$ \\
\hline \multirow{2}{*}{1} & HK & 42 & 85,7 & $28,24 \pm 0,69$ & 17,31 & 0,9257 \\
& LK & 7 & 14,3 & $15,86 \pm 0,11$ & 3,1 & 0,0743 \\
\hline 2 & HK & 83 & 89,2 & $29,96 \pm 0,49$ & 14,9 & 0,9444 \\
& LK & 10 & 10,8 & $14,62 \pm 0,41$ & 8,82 & 0,0556 \\
\hline Joint group & HK & 125 & 88,02 & $29,43 \pm 0,46$ & 16,51 & 0,9381 \\
& LK & 17 & 11,98 & $15,06 \pm 0,53$ & 13,14 & 0,0619 \\
\hline
\end{tabular}

\section{Conclusion}

The data obtained in the study and presented by us in the tables allowed us to draw the following conclusions:

- In domestic reindeer, a clearly expressed polymorphism in the level of potassium in the blood was revealed, due to genetically controlled high NK (alleles KhKh) and low LK (alleles KLKL, KLKh) concentration.

- The average level of potassium in whole blood in the studied population of reindeer is $26.94 \pm 0.56 \mathrm{meq} / \mathrm{l}$ with a variability of $24.61 \%$.

- It was revealed that the average level of potassium in whole blood by sex and age was distributed as follows: whales $22.97-24.19-25.80 \mathrm{meq} / \mathrm{l}$ with $\mathrm{P} 1>0.05, \mathrm{P} 2>0.05, \mathrm{P} 3>0$, 05; bulls had indicators significantly higher than 28.37 - 29.41 - 29.58 meqv/l, with P1>0.05, P2>0.05, P3> 0.05 , the young showed intermediate indicators $28.13-27.37-27.61$ at P1>0.05, P2>0.05, P3> 0.05 . The intragroup variability in potassium content in whole blood ranged from 15.5 to $31.05 \%$.

- It was found that in reindeer the ratio of high-potassium (HK) type animals is $88.02 \%$ and low-potassium (LK) type $-11.98 \%$, while the gene frequencies for high-potassium animals are 0.9381 and low-potassium ones -0.0691 . 


\section{References}

1. Kushnir A.V. Comparative analysis of the ecological-genetic and physiological foundations of animal resistance to extreme environmental conditions (on the example of cattle and reindeer),. 53 (1998).

2. Zhang W., Iso H., Ohira T., et al. JACC Study Group. Associations of dietary magnesium intake with mortality from cardiovascular disease: the JACC study // Atherosclerosis, 221, 587-595 (2012).

3. Kamenek V.M. The role of biochemical polymorphism in the ecological and genetic differentiation of animals: author, 36 (1996).

4. Yuzhakov A.A., Mukhachev A.A., Shubin P.N. Economic use and ecotypes of reindeer of the Nenets breed, Sib. vestn. s.-kh. science, 1-2, 53-58 (1994).

5. Machakhtyrov G.N. Ecological and physiological features of the adaptation of the reindeer in the conditions of the taiga zone of Yakutia, 18 (2006).

6. Kushnir V.A., Yuzhakov A.A. The adaptive significance of potassium and its polymorphism in blood concentration in domesticated reindeer, Scientific Bulletin of the Yamalo-Nenets Autonomous District, 8 (95), 121-129 (2009).

7. Sengupta B.R. Distribution of red cell potassium and evidence of its genetic control in buffaloes, J. Agric. Sci., 84, 82, 559-561 (1974).

8. Novak GV, Bodrova LF: Biochemical parameters of the blood of reindeer with different types of feeding, Vestn. state agrarian University of North. Trans-Urals, 3 (26)., 25-28 (2014).

9. Avrilov A.N., Tagirov Kh.Kh. Reproductive ability of ewes when using chemically stable chloride compounds (sodium, potassium) diets, Bulletin of Biotechnology, 3 (20), 4-6 ( 2019).

10. Andrianova EN et al. Potassium carbonate granulated in feeding broiler chickens // Poultry and poultry products, 1, 33-35, ( 2019).

11. Betin A.N., Frolov A.N. Granular potassium carbonate in calf diets, Bulletin of the agro-industrial complex of the Vernevolzhye, 3 (47), 43-46 (2019).

12. Plokhinsky N.A. Biometrics, 364, (1969). 